26) T. D. Beard: AC Liquid-Crystal Light Valve, Appl. Phys. Lett., 22, 3 (1973) 90-92

27) F. J. Kahn: IR-Laser-Addressed Thermo-Optic Smectic Li-
quid-Crystal Storage Displays, Appl. Phys. Lett., 22, 3 (1973) 111-113

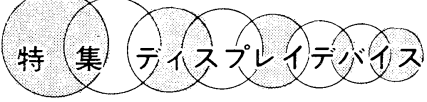

\title{
5-3ＣRT 等を用いた大面積表示
}

\section{1. まえがき}

直視用 CRT として工業的何可能な最大径を越えるよ うな画面寸法一30インチ以上一の場合を“大面積表示” として扱うことにする.

2 次元表示のために 3 次元的奥行きや容積を与えたく ないし, 生産性, 安全性など CRT 単体の直視型には限 界がある.

大面積表示の目的として次の 2 種方向に大別できる.

目的 A ……多人数対象の大面積表示

目的 B ……映像再生の高品位化, 高忠実度化

前者の方向は，教育あるいは広報用の $2 \sim 5 \mathrm{~m}$ 幅級映 像再生装置として，テレビの初期時代汃ら数多くの試み や小規模の製品化が種々行なわれて実用化されて来た。

目的Bの方向は, $6 \mathrm{MHz}$ 幅とか $7 \mathrm{MHz}$ 幅とかに規 定された現行テレビ方式をささえる諸技術からの質的脱 皮を目指すむので，映像再生の高忠実度化の前提技術之 して, 臨場感のある大面積表示方法が要求され始めた. これは $1 \mathrm{~m}$ 幅ぐらいの画面で “ホームビデオシアター” を小人数の一般家庭に実現させるととを目標とする。ま た，コンピューターディスプレイとしての要求も多い.

これら大面積表示に, CRT の直視式は無理としても， CRT などの管球技術を利用するととで目的を果せる場 合も多く，ここでは最近の実例をあげて，大面積表示の カラー化を主体に解説する.

\section{2. 大面積表示の用途と主性能}

\section{1 画面寸法と輝度出力の関係}

表 1 で必要と思われる実用輝度（スクリーンからの） 範囲を，AとEは周辺光の明るい場所での使用が大半と 考光，逆にDは視聴に専念する暗さを与えうる状態に限

"5-3 Large Screen Video-Display Methods of CRT and Others" by Satoshi Shimada (SONY Corp., Tokyo)

$$
\text { ソニー株式会社島田聰 }
$$

表 1 用途別での必要な画面サイズと実用輝度

\begin{tabular}{|c|c|c|c|c|c|}
\hline & 用 途 別 & 対象人数 & 画面サイズ & 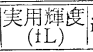 & impact量(比) \\
\hline A & $\begin{array}{l}\text { 通常の直視型家 } \\
\text { 庭 }\end{array}$ & $1 \sim 7$ & $\frac{12 \sim 25^{\prime \prime} \text { diag. }}{(25 \sim 50 \mathrm{cmW})}$ & $30 \sim 100$ & $\times 0.3 \sim \times 3$ \\
\hline B & ホームシアター & $1 \sim 10$ & $\frac{30 \sim 60^{\prime \prime} \text { diag. }}{(60 \sim 120 \mathrm{cmW})}$ & $3 \sim 30$ & $\stackrel{\times 0.15}{\sim \times 6}$ \\
\hline C & 教室, 研修会用 & $10 \sim 70$ & $\frac{30 \sim 70^{\prime \prime} \text { diag. }}{(60 \sim 140 \mathrm{cmW})}$ & $5 \sim 100$ & $\stackrel{\times 0.2}{\sim} \times 25$ \\
\hline D & 講堂, 劇場用 & 100 & $\frac{80 \sim 300^{\prime \prime} \text { diag. }}{(160 \sim 600 \mathrm{~cm} \mathrm{~W})}$ & $5 \sim 20$ & ${ }^{\times 1} \sim \times 100$ \\
\hline E & $\begin{array}{l}\text { 公衆, 宣伝, 広 } \\
\text { 場用 }\end{array}$ & $10 \sim 1000$ & $\frac{30 \sim 500^{\prime \prime} \text { diag. }}{(60 \sim 1000 \mathrm{cmW})}$ & $30 \sim 300$ & $\stackrel{\times 1.5}{\sim \times 3000}$ \\
\hline
\end{tabular}

り， B と C は部屋を暗くして再生する場合から明るい所 で使用したいケースまであるすのとして示した.

表 1 亿示した “impact 量 (比)”之は, 視聴者 1 人当 りの眼に入る所要全光量を,

$$
\begin{aligned}
{[\text { impact量 }} & =[\text { 輝度出力 }(\mathrm{fL}) 〕 \times[\text { スクリ } \\
& \text { 一ン面積 }(\mathrm{sq} \text {-inch }) 〕
\end{aligned}
$$

として定義した值で, $70 \mathrm{fL}$ 出力の 17 インチ直視型 ならびに $50 \mathrm{fL}$ 出力の 20 インチ直視型を基準 1 とした 倍数で示しておく(両基準型ともに(2)式による impact 量は, 約 $1 \times 10^{4} \mathrm{fL} \cdot \mathrm{sq}$-inch である).

図 1 亿表 1 を図示するが，A図では四角範围内で打の おのの目的に対応した実用領域が別個にあるとと，B図 は使用目的別の必要な impact 量の所要範囲を示してい る.

視聴に専念しやすくする手段として，画面を大型化す るととは意味があるが，同時化画面周辺を暗くし周辺物 体に気づきにくくするととす “尃念”させるととを助け るから，少なくとも用途 B および C 亿関してはAと同 程度の impact 量を各人当りに与えるようにすれば，実 用範囲に入る.

また図 1A は明ら加大型画面といっても, 用途によ ってB〜Eの 4 種に区別して具体化する必要のあるとと を示している. 用途Bについては“relax に専念”させる 範团で周辺光環境を考慮してもよいが, 用途Cでは教育 

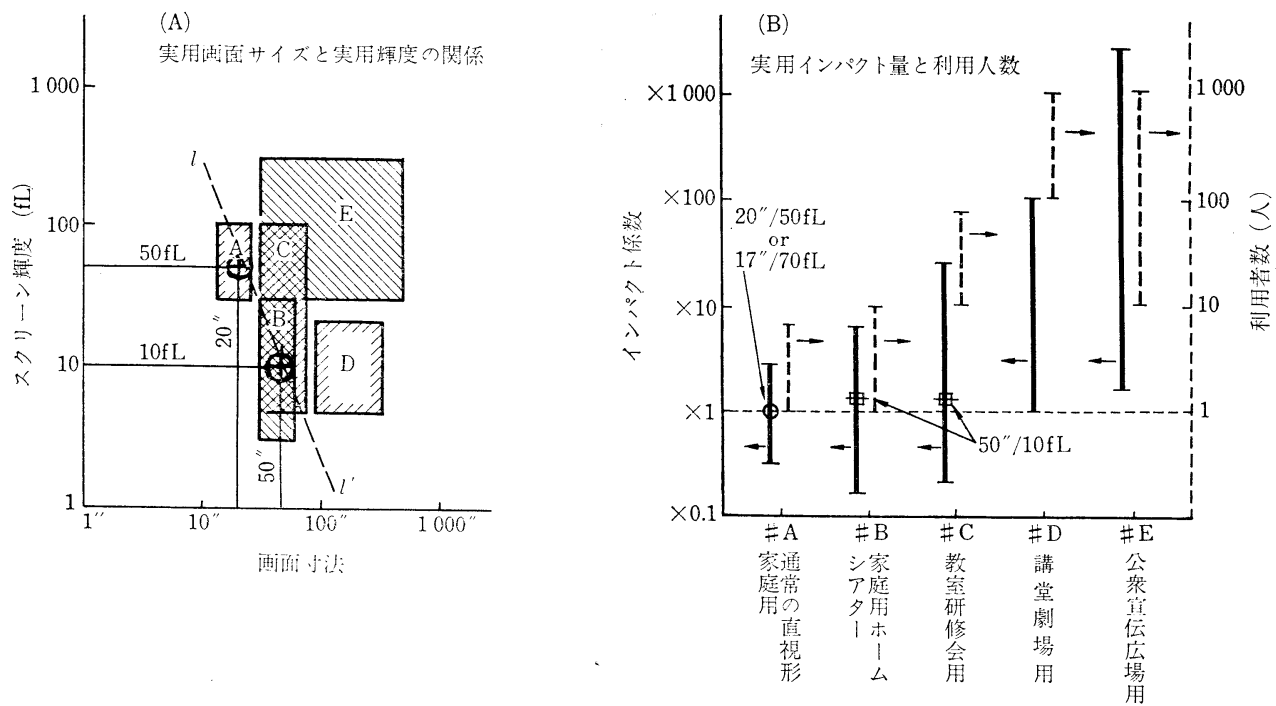

図 1 サイズ, 輝度, impact 必要量の図解

機器として筆記のできるような周辺光環境までをも力バ 一できることが望まれる.

現行の標準テレビ画面絤横比 $4: 3$ で以上を示した が，画面の大型化ととむに aspect-ratio を $5: 3 \sim 2: 1$ と，より横長くすることも将来具化体されようが，異な る縦横比の画面間で用途に応じた画面サイズを比較する 場合には“画面の高さ”で大小ないし最適値を求めるの がよい.

図 1 の中の@印は筆者らの開発したシステムの值をカ ラーの実用例として示し, 破線 $l l^{\prime} は$ そのシステムの能 力のままで函面サイズを変えた場合の穓度出力の変化傾 向を表わしたものである。

\section{2 映像再生の高品位化と画面寸法の関係}

多人数を対象とする大型画面は，ちょうど搪声装置に 相当するわけで，通常のテレビ画質をそのまま拡大する だけですよいと理解されよう.

ホームビデオシアターを目指す場合は, 当然現在の直 視型よりあ何らかの “高品位化”が要求され，乙れはラ ジオに対するステレオ装置の関係に相当する. 走查線数 や輝度/色帯域を現行の標準方式のままで大型化すると きの, 高品位化要素の有無を以下にさぐる.

(1)“画像の高品位化”を映像再生における“reality （迫真性）の追求”之換言することで，実物大に再生し 実際の距離感覚で見られるようにすることが，視覚的な 迫真性 (臨場感) を高める効果大で, 大型化の必要性 があって, 表 1 の用途 B む 40〜50”diag. $(80 \mathrm{~cm} \sim 1 \mathrm{~m}$ 湢）の画面サイズが, 家庭用としての reality 最適サ イズとなろう. real-size の親密感も生じ 4〜 7H の比較 的近距離で視聴したがる傾向も加味してよい.
（2）スクリーン位置を意識しにくい配慮李必要で, (1)画面を大きくし遠くで見る，(2)画面は凸面よりも平面 が, さらに凹面がよい，(3)周辺物体や周辺光環境の印象 を弱めることなどが具体策である.

（3）現行の 525 本方式で走查線の“粗さ”が問題で あったのは, 最近のカラー受像管の場合よりも過去の 21〜24インチの白黑管の場合であった. それらは中間 階調での電子ビームの集束が良過ぎて，たとえインター レース動作が完全で 500 本の重直解像度を示しえても, 肉眼には奇数フィールドと偶数フィールドの走查線構成 を別個の時間点の存在と識別させ，250 本の粗さに感じ やすかった，現在のカラー受像管では電子ビーム利用率 が白黒管の 1/5 1/7亿過ぎないし，3色螢光体配列構造 という絵素数を制限する基本形式とが逆に幸いして, 走 査による“line-structure”は白黒管ほよ゙には顕著では ない，密度変調でビーム径が変化しにくい CRT に改良 することで高品位化が可能である.

（4）用途Bの場合 “relax に専念”して視聴するには 周辺光を適度の暗さに保つのがよく, との周辺条件を加 味したスクリーン輝度は 3〜30 fL が適值となることか ら, 肉眼のフリッカー周波数は直視型の現状よりあ低下 し，実質 500 本の現行走査線構成を “同時に認識”する 効果も生ずる。

（5）投写式の場合は, さらに光学系で, 走査線間除 を電子系におけるようなビーム差を生ずるとよなく, RGB 3 色配列のぼかしとともに一様に平滑化できて, 高品位化の一助となしうるのであるが, 過去の例では逆 に投写用小型 CRT のハレーション現象や光学投写系の 収差など，発光後の光利用率の向上を主にするために， 


\section{5. 大面積表示}

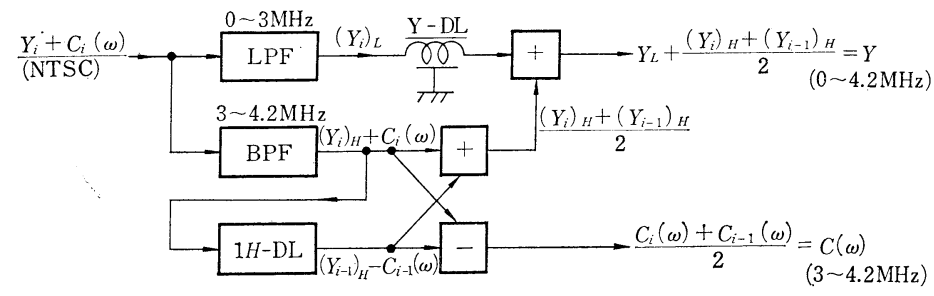

図 2 NTSC 形式の標準規定信号時の高品位化分離方法
(2) contrast-ratio …‥コントラスト比

(3) sharpness……鮮鋭度

（4） colorfulness……彩色性

(5) smoothness

……画面のなめらかさ

(6) decay-time......残像

大面積表示方式を検討する際の追加 事項として,

（7） picture-size......大型化の限界

（8） set-size/(9) set-depth…...装置容積 - 奥行

(10) power-consumption......所要電力

(11） portability……可搬性・移動性

（12） adjustability……調整の難易性

(13) stability……安定性

(14) safetiness……安全性

(15) life……寿命

(16) service-ability……設置・保守・改修

（17） product-ability……製品化の難易

（18） cost……費用・価格

以上の 18 項目に関して，表 1 に示した用途 D执よび $\mathrm{E} の$ 目的内のものは必ずしも全項目を満足しなくても実 用可能であるが，用途 B および C として実用化するた めには，すべての項目に一応の満足がえられる必要があ り，白黒式に比してカラー化された製品として成功した ものはきわめて少なない。

\section{3. 電球マトリックス表示方式}

この方式は，フィラメント発光以外に，ガス放電形式 の管球を利用してもよいのであるが，フィラメント電球 で実用化される場合が多い，その理由として，保守に市 販球を利用すればよいということああるが，エレメント 輝度が集中的で高いことああげられる.

\section{$3.10 \mathrm{~N} / \mathrm{OFF}$ 表示形式}

$N($ エレメント $)=m$ (行) $\times n$ (列)のマトリックス表示 にN本の信号ラインを引くような原始的方法も， $N=$ 5000 本くらいまでは実施していて（たとえば東京銀座の ペプシ広告), 全エレメントが同時式動作となるので, 定格の電圧・電流值で点火でき, 屋外広告用として古く からある.

$N$ エレメントの発光制御を $m+n$ (本)の制衔系ですま せる，いわゆるマトリックススキャン形式で ON/OFF の白黒映像を出すためには図 3（b）のような側流塞止用 ダイオード $\mathrm{D}_{i j}$ をランプ $\mathrm{L}_{i j}$ に直列挿入する必要があ り，パルス点火なので瞬時電圧電流值を何倍もにふやす

\section{4 大面積表示方式の性能検討事項}

映像表示の一般的な画質項目として，

(1) brightness……輝度出力 


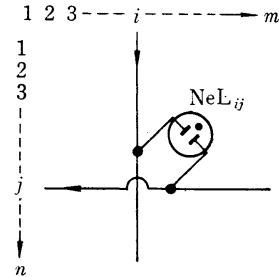

(a) 放電管

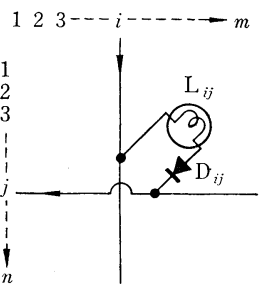

(b) フィラメント発光管:

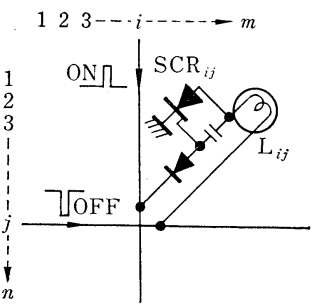

(c) 持続占火

図 $3 X Y$ マトリックス方式におけるパルス点火方法



写真 1 查京, 後楽園球場の影絵表示装置

必要もある. 図 $3(\mathrm{c})$ に示す方法によれば $\mathrm{SCR}_{i j}$ がホー ルドして通常の定格で点火できる.

写真 1 の実例は, 富士電工が東京, 後楽園球場に昭和 45年設置した超大型表示装置で, 中央部の影絵表示部分 だけでも， $15 \mathrm{~m}(\mathrm{~W}) \times 5.5 \mathrm{~m}(\mathrm{H})$ の画面を $(m=145) \times$ $(n=55)=(N \fallingdotseq 8000$ 個 $)$ の電球とサイリスタで構成させ, 図 3 ( c ) に類する制御方法で ON/OFF 動画をテレビカ メラから導いている.

\section{2 モノクローム映像の表示}

階調も正しく表現する形式は, 電球マトリックスの場 合はごく局部的な実験の例はあるが，白黒映像を全画面 表示して実用化した例はない. 2.3 節にて指摘の印象力 が不充分と考えられるし, 熱発光形式では階調表現をし ようとすると白 $\rightarrow$ 赤と大幅に色温度も変化する.さらに 図 3 (c) の点火制御法は採れず, 図 3(b)で超大型化を 実施するほどの制御素子が容易にはえられないなどの理 由による.

図 3（a）の放電発光をPWM制御すれば白色螢光体で 目的を達しえられようが, この種の $X Y$ マトリックス式 大型映像表示の場合は, 白黒表現もカラー表現も技術的 な差違は少ないので，次の例のようなカラー化が得策で ある。

\section{3 カラービデオパネル方式}

昭和 43 年に筆者らは, 写真 2 に示すようなフィラメ ント豆球式のカラー映像再生装置を試作完成させ, カラ



写真 2100 型カラービデオパネル

一ビデオパネルと命名して一般公開した.

$m=300$ 列, $n=260$ 行で $N=78,000$ 総エレメントに よって, $2 \mathrm{~m}(\mathrm{~W}) \times 1.5 \mathrm{~m}(\mathrm{H}) \equiv 100$ in diagnal のカラ 一画面を奥行 $25 \mathrm{~cm}$ の装置として構成させた，RGB の3色化は色フィルターを付すことで行ない，3色映 像信号を各200チャネルに sampling-\&-holding した PWM 信号に変換して, 各エレメントに図 3(b)の形 式で $\max 120 \mu \mathrm{s}$ 幅/60 Hz 繰り返しのパルス点火をさ せる回路方式を確立させた，原理的には PAM 点火で あよいのであるが，回路素子のばらつきの影響のない PWM 点火方式を選んだ.この回路方式はプラズマ式 などの小型 $X Y$ マトリックス映像表示の場合にも基本 となっている.

この 100 型力ラー映象再生装置は, $100 \mathrm{fL}$ max $の$ 白ピ ーク出力を $10 \mathrm{~kW}_{\max }\left(30 \mathrm{~V}_{\mathrm{DC}} \times 300 \mathrm{~A}_{\max }\right)$ の電源でえ ており，CRT 形式で問題の“ブルーミング”現象がな いので, 26,000 RGB トリオ数がカラーCRT の1/10 に 過ぎない割には，カラー映像の鮮鋭度が比較的良いこと 之, RGBの色フィルターが光エレメントを执执てい るために周辺光を吸収する実質的な黑色スクリーンを形 成して，高コントラストとなるなどの特長があった。ま たフィラメント径が細いので, 残像時間は $1 / 60 \mathrm{~Hz}$ 末満 で問題はなかった.

しかし, 条状のむらの許容レベルは, 点版のむらの場 


\section{5. 大面積表示}

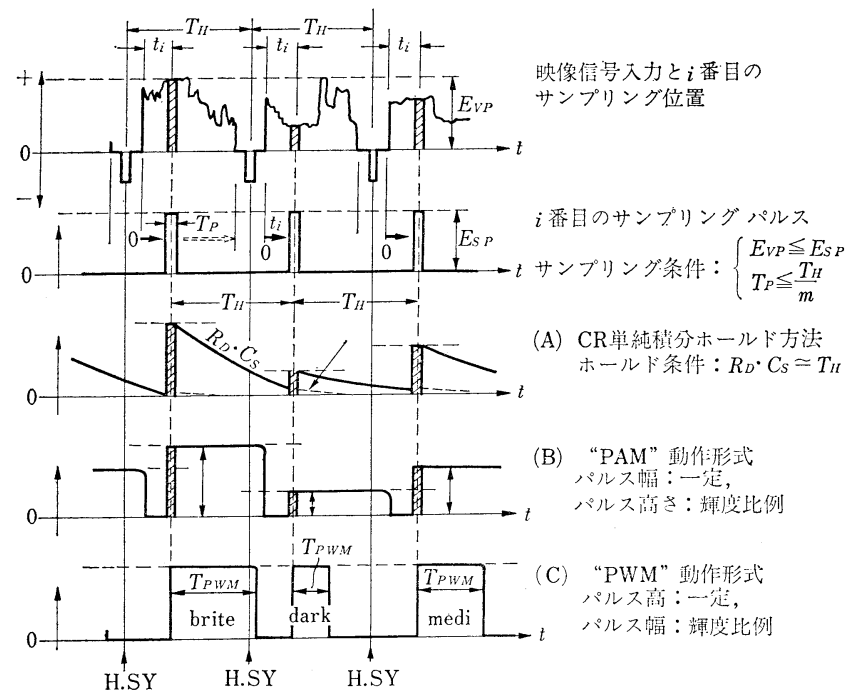

図 $4 \quad X Y$ マトリックス形式の映像階调表現方法

合に比し，はるかに厳密に押える必要を認めた。乙れは CRT 形式に対するXY マ $\mathrm{X}$ リックスディスプレイデバ イスのすべてに捻いて留意すべき問題点となろう。

\section{4. 多管配列式 CRT ディスプレイ}

昭和 46 年に NHK 技研は, 松下電器の協力をえて 26 型カラー CRT 3 本をハーフミラー合成して $1 \mathrm{~m}(\mathrm{~W}) \times$ $0.5 \mathrm{~m}(\mathrm{H})$ の $2: 1$ 画面縦横比によるカラーワイドディ スプレイ装置を試作, 公開した. 図 $5(\mathbf{a})(\mathbf{b})$ 亿構成之 走査方法を図示する.

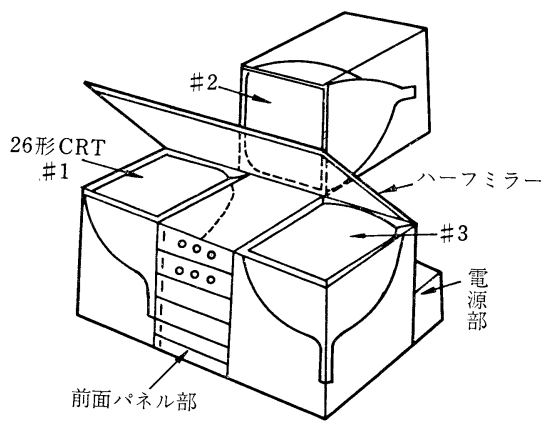

図 5(a) NHK 技研のカラーワイドディスプレイ装置

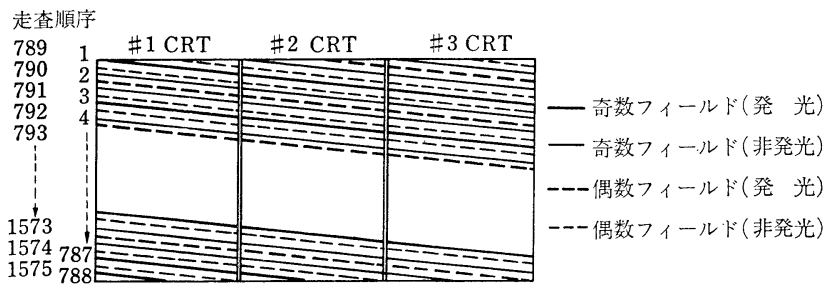

図 5(b) 3 管間の走查合成法
この試作は高品位化ワイドカラー映像再生の 画質を現状技術で可能な手段で実現してみるこ とを主目的とした開発のようである。

このカラー画面の大きさと鮮鋭度の高さに, 公開を見た人は全員感嘆していた，各 CRTを $47.25 \mathrm{kHz}$ (水平偏向), $60 \mathrm{~Hz}$ (垂直偏向) で 3ラインごとに ON して，実質的に現行方式 と同じ $f_{H}=15.75 \mathrm{kHz} ， f_{V}=60 \mathrm{~Hz}, 2: 1$ イ ンターレースのラスターを 3 管分で形成させ,

入力映像帯域を $10 \mathrm{MHz}$ に広げることで 1.5 倍横長の画面上りも大きい水平解像度の增大 (1000 本を目指す) を与えた形のカラー映像再 生である. 3 管間の接ぎ目を気づかれないよう 汇するため，主として走查回路任苦心が払われ ている.

この実験装置は図 5 ( a ) から想像できるよう に相当大容積となってしまい，乙のままで家庭 に将来入りうるわ汀ではないが, $1 \mathrm{~m}$ 幅の大型カラー画 面が高品位化にとって必須条件であり，525本方式のま まであ水平解像度のみ高机ば効果的なととと， CRT 直視式に代るべき新大型ディスプレイ方式開発の必要性 を訴えるに充分であった。

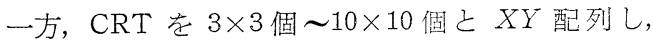
全体として 1 つ大画面化をはかる試みも考えられよう が，接ぎ目をなくする妙手がないので，広告用としての 用途の範囲に限定されることとなろう.

\section{5. シュミット投写光学系による 大型カラー映像表示}

5〜7 型 CRT Kよる白黒用のシュミット投写方式は 古くより実用化されているので, 最近の技術問題として のカラー化作定してシュミット式を解説する.

\subsection{3 列シュミット式}

Philips 社が用途 D あたりをねらっていちはやく開発 し，20 インチ級の rear-projection 形式までも製品化を ねらったととが 1950 年代にすでにあった. 調整が完全 にできたならば，暗い部屋で高画質が得られるのである が，図6の原理図が示すように，3色間のレジ ストレーションを完全に得ることが至難の技で ある。

シュミット式の補正レンズを付した凹面鏡に よる拡大集束方法（以後シュミット式之略 称）の類は, 光源からの光利用率が良い反 面,

（a）投写点における焦点深度が非常に浅く フォーカス調整がクリティカルなとと， 


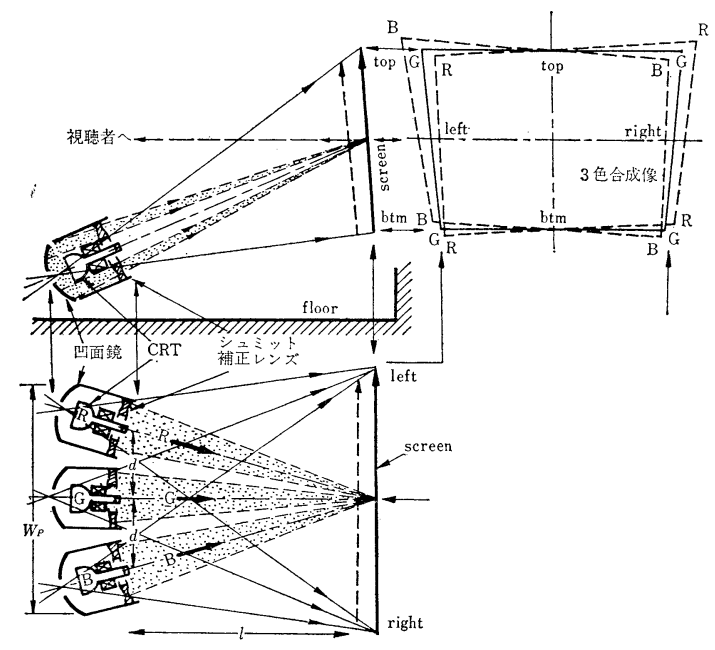

図 6 3列シュミット式の原理図

(b) 光源像 (CRT 径) が小さいために, 元の発光像 がぼやけやすいとと，螢光面が高熱となるとと.

の基本問題が 2 点存在する。（a）は，3列シュミット式 の場合には特に，投写画面サイズを変更しようとした り，設置するたびにフォーカス/レジストレーションの 至難な再調整を要するととになる。

シュミット式光学系の $F$ 值は 1:0.6ぐらいで非常に 利用率が高い反面, 光学系外径 $\phi_{L}$ に比し光源像外径 $\fallingdotseq \phi_{\mathrm{CRT}}$ が 1/2 1/4 と小さくなるし, 各色光源像間隔は $d \geqq \phi_{L}$, プロジェクター部横幅は $W_{P}>3 \phi_{L}$ とそれぞれ 困る值になる。

投写距離は拡大率 $m$, 焦点距離 $f$ として, ほぼ,

$$
l \fallingdotseq m f=m F \phi_{L}
$$

として示されるとてろから，

$$
\frac{d}{l} \geqq \frac{1}{m F}, \frac{W_{P}}{l}>\frac{3}{m F}
$$

となってしまう. 5 in $\phi$ の CRT で 50 100 in $(m=x$ 10〜×20) のカラー再生を図 6 亿示す 3 列インライン形 式で具体化した場合, $\phi_{L} \fallingdotseq 30 \mathrm{~cm} \phi, F \fallingdotseq 0.6, f \fallingdotseq 17 \mathrm{~cm}$, $l \fallingdotseq 1.7 \mathrm{~m}(50$ in $) \sim 3.4 \mathrm{~m}(100 \mathrm{in}), d / l>0.2 \sim 0.1, \quad W_{P}$ $\geqq 1.0 \mathrm{~m}$ となることになる.

拡大率 $m$ を $\times 50$ × 100 とすれば， $d / l$ は 0.04〜0.02 となって 3 ビーム形式の通常のカラー管に打ける $d / l$ 相

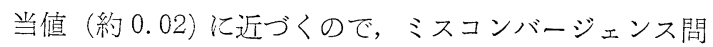
題は直視型なみとなり, 拡大画面サイズに比しプロジェ クター部は小型となるわけであるが，今度は前記（b ）の 別の基本問題にぶつかり, 蟹鋭度と輝度が両立できなく なる。

図 7 亿図解するような $15 \mathrm{~cm} \phi$ くらいの凹面鏡内臟の 特殊管の 3 列式す試みられてはいるが，光源像は1.5 个

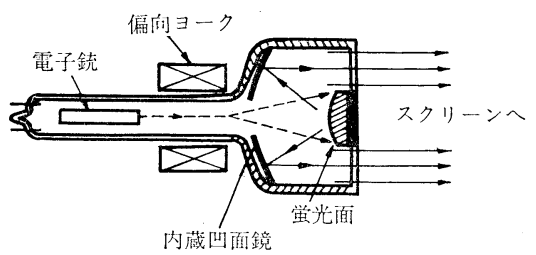

図 7 管内部に凸面鏡を有する特殊管を用いた シュミット方式

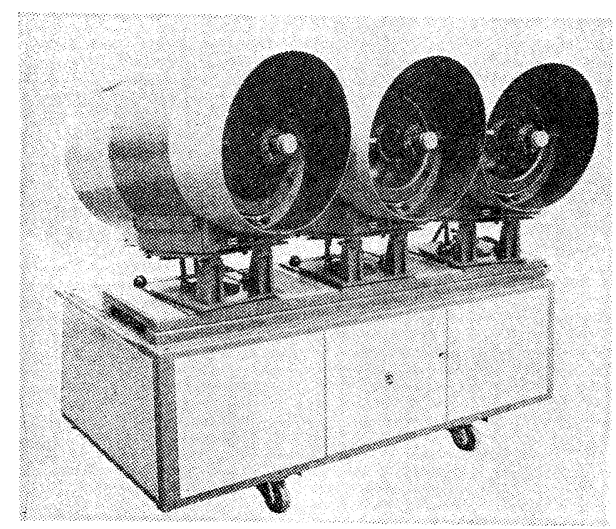

写真 3 Philips の3列シュミット式大型力 ラ一胦像投写装翼

ンチ CRT 相当で, 營光体の飽和現象も含め前記 (b) 項 問題に悩むとととなろう。

写真 3 亿図 6 形式の製品例を示ずように, 表 1 の用途 Dの範囲に限定して䒠用化されてはいるが，白黒用の 3 倍の佂格ではとうていすまないようである。

\section{2 単管カラーシュミット式}

白黑用の投写型 5 インチ CRT なら $2000 \mathrm{fL}$ 以上の光 源輝度が出せる. 投写専用の 5 インチカラー管ができた ならば, 単一光学系のままで容易に大型カラー画面を実 現しうるわけであるが， 3 ビーム形式に属するカラー管 では色選別電極板を内臟しており，そ扎による電子ビー 厶利用率が 15 23\% と白黒管の 1/4 1/6 亿過ぎない ため，5インチ管で $500 \mathrm{fL}_{\max }$ と，カラーの輝度は白黒 の場合の $1 / 5$ くらが限度であり, それ以上は小型のた めに特に色選別電極板のヒートシンクに無理が現われ るし，また 3 色螢光面の $R G B$ トリ才配列の “きめ”を 細かくしにくい.

さらに複雑な 3 ビーム用電子銃構造のため, 白黒式の 場合の $50 \sim 70 \mathrm{kV}$ 屯の高圧印加は困難で, 光源像自身 が総合的に“低品位化”する傾向となりやすい.

\section{6. 光学繊維束による CRT 拡大方式}

オプチカルファイバーを有機材料で量産化すること と, 整然とした $X Y$ 拡大配列構造に積重㸚る“自働織 


\section{5. 大面積表示}

機”を開発するとととを前提にすれば，カラーで実用難 となった他の諸方式に対して $1 \mathrm{~m}$ 幅くらいのカラー表示 方式として相対的に重視すべき方式かむしれない. 数 $\mathrm{cm}$ の厚味の超薄型は無理としても図 8 のような構造で かなり薄型化しうる.

また，画面拡大といってファイバーの出口を朝顔状に 太くしてやる必要はない. 出口部は入口端之同径 $\phi_{P F}$ の ファイバーを拡大率 $m$ だけの間隔 $p_{S} \fallingdotseq m \phi_{P F}$ で縦・横 に分散配列させ，その間の不要面積はすべて黑色化して やるととで，理想値としてコントラスト比（外光に対す る）を少なくとも約 $m^{2}$ 倍にも改善可能である.

図8 の場合のスクリーン輝度 $B S$ は, 無機ガラス製光 学繊維によるフェースプレートを持つ専用カラー管の内 側の輝度 $B_{0}$ (通常のカラ一管の輝度に相当) に対して 次式で比例計算でき，

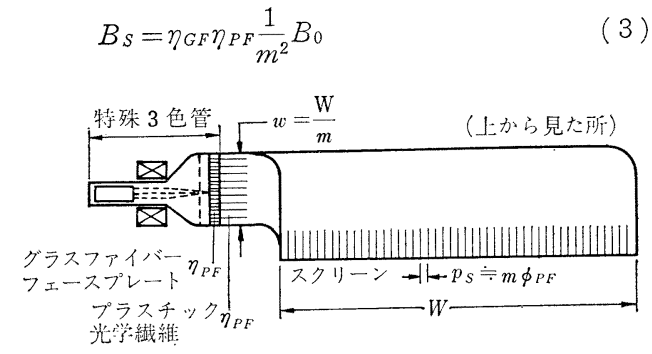

図 8 光学瀻維束と 3 色管を直接結合した方式

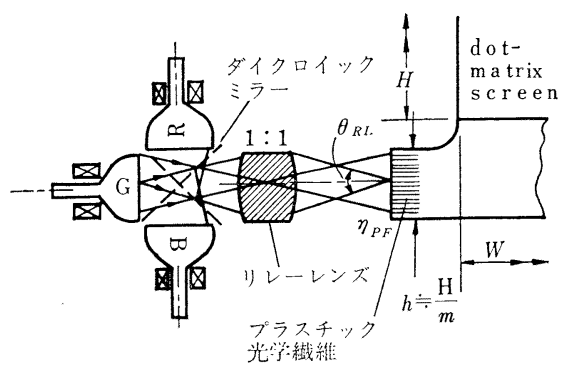

(㓩から見たところ)

図 9 光学結維束と 3 管とリレーレンズの組合せ方式



図 10 光学繊維の性質
オプチカルファイバーの束の有効断面積率その他できま る光伝送効率が $\eta_{G F} \fallingdotseq \frac{1}{2}, \eta_{P F} \fallingdotseq \frac{1}{3}$ でできてむ， $B_{0} \fallingdotseq 500$ $\mathrm{fL}$ 出力の 7 インチ 3 色管から 50 インチ像に伸ばすと, $B S \fallingdotseq 1.7 \mathrm{fL}, 40$ インチぐらいでも $2.5 \mathrm{fL}$ 亿過ぎない. 図 9 に示すようなりレーレンズ再結像形式の 3 管式にす れば大幅な輝度向上が期待できる. 3 管式で得られる合 成 $B_{0}{ }^{\prime}$ は 3 色管の約 5 倍, $2500 \mathrm{fL}$ くらいは出しうる し, この場合は( 3 )式の $\eta_{G F}$ に相当する損失はほとん ぞないので，スクリーン輝度は $B_{S} \fallingdotseq 15 \mathrm{fL}$ (50 インチ)〜 $22 \mathrm{fL}$ (40 インチ) と推算できる.

問題は指向性で, 図 10 のように光学瀻維に臨界角 $\theta_{P F}$ があり, 図 9 のレンズ系が $\theta_{R L}<\theta_{P F}$ ならば光学瀻維の 出口の拡散角 $\theta_{S}$ 屯 $\theta_{R L}$ となり, 四 9 の機成では $\theta_{R L} \leqq$ $40^{\circ}$ が可能值であって, あし光学纎維の出口を “粗面” として拡散角 $\theta_{S}$ を所望值まで拡げたとすると, スクリ ーン輝度 $B_{S}{ }^{\prime}$ は $\left(\theta_{R L} / \theta_{S}\right)^{2}$ 倍に低下してしまう.

$$
B_{S^{\prime}}=\left(\frac{\theta_{R L}}{\theta_{S}}\right)^{2} B_{S}=\eta_{P F} \frac{1}{m^{2}}\left(\frac{\theta_{R L}}{\theta_{S}}\right)^{2} B_{0}^{\prime}
$$

$\theta_{S} \fallingdotseq \theta_{P F} \fallingdotseq 70^{\circ}$ と光学繊維出口を粗くして, $\theta_{R L} \leqq 40^{\circ} \mathrm{max}$ のレンズ系とすると， 3 管式の実質スクリーン輝度は $B_{S^{\prime}} \leqq 5 \mathrm{fL}$ (50 インチ) 7fL (40インチ) くらいに下り, このままでは通常の直視型カラー受像機の $1 / 10$ が精一 杯ということになる.

\section{7. 通常レンズ系による CRT 投写拡大方式}

CRT の螢光像を光学投写する方法は, 几面鏡亡収差 補正レンズの組合せで成るシュミット式に限るとの先入 観が専門家に定着して長年月がたっていた。 通常のレン ズ系ではF 3.5 くいが利用限度と考え, そ机に比し実 効 $F$ 值として $1: 0.6 \sim 0.8$ あの高能率光学系をシュミ ット式でえられると思うからにほかならなかった。しか し, シュミット式の場合, 同時に $5 \sim 7$ 型 CRT と小面 積光源になり, 非飽和総出力光量が面積に比例して少な くなるととにも留意するべきであった，

昭和 47 年初春開発, 発表し, 今春より市場化し始 めたトリニトロン式のソニーカラービデオプロジェクシ ョンシステム (写真 4 参照) は, 50 型カラー映像を 10 fL 以上の輝度出力で再生する高性能を出したが, その 内容は 13 型投射専用トリニトロン管とF 2.0 の通常 レンズ系の組合せによる非専門家的なほどに初歩原理的 手法に過ぎない，投写スクリーン側にも高輝度化のため のノルマを掛け, システム全体を同時に開発したために 飛躍的な性能向上（約 100 倍の輝度增大）ができたので ある。

また，乙のシステムは当初より表 1 の用途Bすなわち 




写真 4 カラービデオプロジェクションシステム (スクリーンは 50 型, $1 \mathrm{~m}$ 幅）(ソニー)

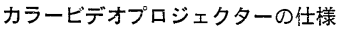

有効画面サイズ：50型 (対角上にて)

道 視 符 团: 3〜 15m/50 型スクリーンにて 中心から左右約 $40^{\circ}$ 以内

投 写距 離: $1.5 \mathrm{~m} /(50$ 型スクリーンにて $)$

映 像 管 輝 度: $500 \mathrm{fL}$ 以上

スクリーン輝度出力：10 乩以上（50型スクリーンにて）

投写コントラスト比： $34 \mathrm{~dB}$ 以上

信 号 方 式：日本䌘準テレビ方式 (NTSCカラー方式)

映像带 域: $4 \mathrm{MHz}$

音声 方 式: スクリーン反射式

消費電 力: $185 \mathrm{~W}$

外形寸 法: 44 (愊) $\times 73$ (高さ) $\times 49$ (奥行) $\mathrm{cm}$

重量: 約 $40 \mathrm{~kg}$

\section{ビデオスクリーン部}

スクリー ン：兾方指向性高能率金属スクリーン

外形寸法: スクリーン部 110 (横) $\times 83$ (预) $\mathrm{cm}$ スタンドと組合せ時 110 (幅) $\times 150$ (高さ) $\times 41$ (舆行) $\mathrm{cm}$

ホームシアターとしての必要性能の範囲で，最適方式を 選んだすので，用途Cまでのすべてを必ずし屯満足させ るわけではない，2.4 節に列記の18項目のすべてに 1 $\mathrm{m}$ 幅画面級のディスプレイ方式として，はじめて一応の 満足がえられたので製品化されたといえよう.

\section{1 投写スクリーンの指向性と利得}

CRT を光源像とした投写方式を一般化した光学系之

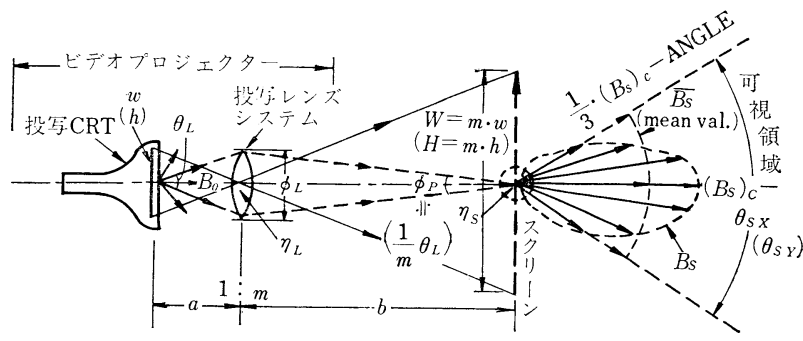

図 11 CRT を光源像とした投写方式の一般化した光学系
して示した図11について，スクリーンからの有効全光出 力一その輝度指向特性を点線 $B_{S}$ で示す一を，中心軸方 向の出力輝度 $\left(B_{S}\right)_{C}$ の $1 / 3(-10 \mathrm{~dB})$ 亿落ちる角度範囲 (水平方向 $\theta_{S X}$, 垂直方向 $\theta_{S Y}$ ) 内に平均化した值をスク リーン輝度 $\bar{B}_{S}$ とすると，次式が成立する.

$$
\bar{B}_{S}=\eta_{L} \eta_{S} \frac{1}{m^{2}} \cdot \frac{\theta_{L}^{2}}{\theta_{S X} \theta_{S Y}} B_{0}
$$

ここに $\eta_{L}$ : レンズ系その他 CRT からスクリーンまで の間の光伝送効率， $\eta_{S}$ : スクリーンへの総入力に対する 必要方向側への総出力の比（スクリーン損失を意味す る), $\theta_{L}$ : レンズ系への実効取込み角（実効径 $\phi_{L}$ 己 $a$ との比できまる）を意味する，また冒頭の表現を次式 で示す。

$$
\begin{aligned}
\iint_{S} B_{S} d \theta_{x} d \theta_{y} & =\left(B_{S}\right)_{C} \iint_{S} k\left(\theta_{x}, \theta_{y}\right) d \theta_{x} d \theta_{y} \\
& =\bar{B}_{S} \theta_{S X} \theta_{S Y}
\end{aligned}
$$

プロジェクター部の光利用率 $\eta_{P}$ と，スクリーン利得 $G_{S}$ は (5) 式を分割しておのおの次の式で表わされる.

$$
\begin{aligned}
& \text { 〔source-efficiency]: } \eta_{P}=\eta_{L}\left(\frac{\theta_{L}}{\pi}\right)^{2} \\
& =\eta_{L}\left\{\frac{2}{\pi} \tan ^{-1}\left(\frac{m}{2(1+m)} \cdot \frac{1}{F}\right)\right\}_{(F: \text { レンズの } F \text { 値) }}^{2} \\
& \text { 〔screen-gain〕: } G_{S}=\eta_{S}\left(\frac{\pi^{2}}{\theta_{S X} \theta_{S Y}}\right)
\end{aligned}
$$

(5)(7)(8)式より

[screen-brightness]

$$
\bar{B}_{S}=\frac{\eta_{P}}{m^{2}} G_{S} B_{0}
$$

以上の関係式は次に列記するように基本方式を定量的 に比較し，具体化する方向を与えてくれる.

推考-a： $\eta_{P}$ 值〔( 7$)$ 式〕のみで比較する限りは，図 12のような通常レンズ投写式は 5 章で触れ たシュミット投写式の $1 / 8$ 以下の光利用率 に過ぎないが,

推考-b: 5 インチ単管シュミット式と 13 インチ単 管・通常レンズ式の比較のようにプロジェ クター部外形をほぼ同等な大きさにし て比較するのが適切で， $\left(\eta_{P} / m^{2}\right)$ 值の 形で評価すべきである，後者で前者之 同等值以上屯可能.

推考-c：スクリーンの指向性を強くし，拡散角 $\theta_{S}$ を狭くしてやれば，スクリーン輝 度は $\theta_{S}{ }^{2}$ に反比例して増大するが，

推考- $\mathrm{d}$ : 指向性飞“異方性” $\left(\theta_{S X}>\theta_{S Y}\right)$ を与え ることができるなら，実質視聴領域を 
5. 大面積䒾示

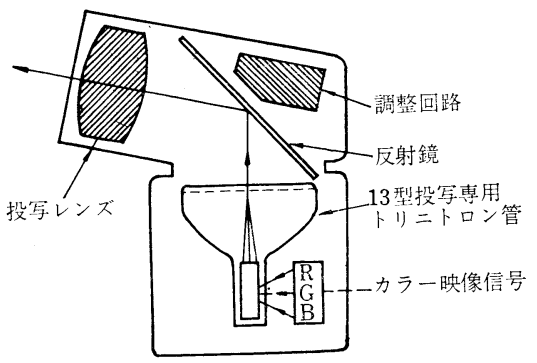

図 12 通常レンズ投写方式

余り狭くしないで $G_{S}$ 值〔( 8 )式〕大幅に 高められる。

推考-e：GS 值が大きくできれば，それだけプロジ エクター部の光出力は弱くてむよい. たと えば $\eta_{S}=0.8, \theta_{S X}=90^{\circ}, \theta_{S Y}=30^{\circ}$ のス クリーンが実現できたとすれば， $G_{S} \fallingdotseq 10$ 倍となり， 5.2 節で否定的だった 3 色単管 シュミット式も輝度に関しては害用域とな り,さらに前記 (b) 項に示した 図12 のよ うな 13 インチ 3 色管による通常レンズ投 写方式という最も初歩原理的な手段でも 50インチ級のカラ一拡大像を実用輝度で出 しうることになる.

推考-f : スクリーンの指向性で $G_{S}$ を高めることは, 同時に周辺光の影響を弱めることにもな る. 特に反射式スクリーンを $\pi>\theta_{S X} \gg \theta_{S Y}$ とできるならば，天井からの室内照明に強 くなり,コントラスト比の実質改善とな る.

以上の推考は，反射式スクリーンによる投写式む rear-projection 形式むと屯に指向性に異方性をむつス クリーンが実現するか否かで，プロジェクター部側の基 本方式の実用化選択基準が大幅に変わるととを意味する 一図 13/(5)式の説明は反射式にも rear 式にあ共通す る一. また，ガラス粒子によるような在来の “高輝度ス クリーン”の類では異方性がないので，スクリーン利得 と視聴領域とが相反している.

そこで筆者らは, micro lens-aperture のXYマトリ ックス配列形式の“black-eye screen” rear-projection 用として考え，反射式の方は金属表面反射作用を異方性 のある粗面化で $\theta_{S X} \gg \theta_{S Y}$ ， と反射分散させるような表面 加工方法を見出し， $G_{S} \geqq 10$ 倍と $\theta_{S X} \fallingdotseq 80^{\circ}, \theta_{S Y} \fallingdotseq 30^{\circ}$ と の所望性能を両形式ともに得た.

反射分散の指向性を与えると同時に，全画面に輝度を 均一にする考慮が必要となり, 図13に図示するような 半径 $r_{S}$ の凹面化も施こした. 結果として, 最適視聴域

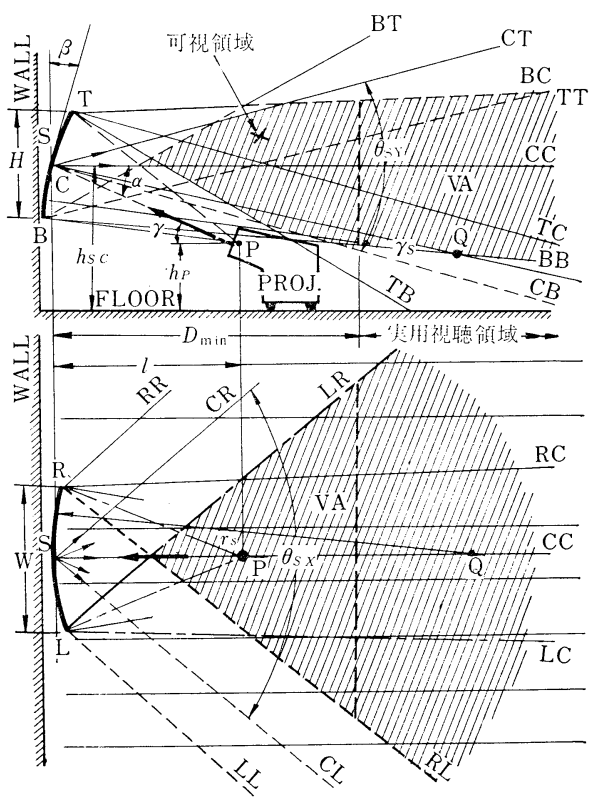

図 13 舆方指向性スクリーンの動作

のみに反射光が分散するようになった．この凹面化は投 写焦点の均一化, 迫真性の向上, 音声反射効果などの付 随効果にも寄与している.

\section{2 高利得型スクリーンを前提とした CRT 投写方} 式

$G_{S} \geqq 10$ がえられれば，50 インチ画面を $\bar{B}_{S} \geqq 5 \mathrm{fL}$ で 光らせるためには F1:2.0 のレンズ系を用いて，12イ ンチ 3 色管で $B_{0}$ を $350 \mathrm{fL}$ にできればよいととが，（5） 式より算定できる.

写真 4 , 写真 5 に示すソニーの投写方式の場合, 投写 専用の 13 インチトリニトロン管を開発一 3 色螢光面部 全般にわたる発光効率の増倍化, アパーチャーグリル等



写真 5 カラービデオプロジェクター (ソニー)

(61) 361 




写真 6 1972-IEEE 大会にソニーが出品した 38 in diag. の COLOR-REAR試作機（左）

の許容損失限界の増強, インライン 3 ビーム単電子銃の 強力化一して, 25インチカラー管程度に $E_{H V} \cdot I_{H V}$ を与 えるととで, $\left(B_{S}\right)_{C}>10 \mathrm{fL} の 50$ インチカラー映像の再 生能力で製品化できている.

トリニトロン管は 3 色の綐縞配列を特長のひとつとす るが，そのために螢光面が円筒面になっており，球面形 状のシャドウマスク式とは異なる．投写式における投写 焦点の均一性を球面上フェースプレート形式よりは良好 にできるという得点あある。

投写距離 $l$ は, レンズ系の大きさ, 画面の均一性, ひ ずみ，スクリーン形状，操作性なご反射式に抬ける実用 設計の要めとなる。最短適視距離 $D_{\min } \fallingdotseq 3 \mathrm{~m}$ (50"pix) として $\fallingdotseq 1.5 \mathrm{~m}$ ぐらいとなる大口径レンズ系 (F 2.0)
$300 \mathrm{~mm} / 15 \mathrm{~cm} \phi)$ を特に開発した.

\subsection{Rear-projection 形式}

rear-projection 形式の中間的試作機は写真 6 に示すよ うな形で, micro lens-aperture 66 万孔の $X Y$ 万リリッ クススクリーンが実質的に 6 章のファイバーオプチック ス形式の光路系を省略し輝度出力の大幅改善をはかった 形ともいえるし，表 1 の用途 $\mathrm{C}, \mathrm{E}$ に広く適するまとま り方向ではあるが，“black-eye screen” 方法で周囲光に きわめて強くはなったおのの， $\bar{B}_{S}>15 \mathrm{fL}$ では写真 6 の 形態での製品化は不充分なので，周辺光環境の抑制要求 の理解されやすい反射式のみが現在製品化されている.

(昭和 48 年 3 月 15 日受付)

\section{〔参 考 文 献〕}

1) 大谷, 久保：高品位テレビ方式汇おける画面形状の検討， NHK 技研月報, 14,5 (1971) 210

2) 橋本：映像表示装置,特公 昭41-20844, 同 42-9222,同 45-20270

3）橋本: 後楽園に設置したマンモステレビ, テレビ全大予，9-23 (1971)


路研・固体画像研共同委，資料 No. 6-2，資料 No. 10. (昭 43. 4. 25)

5) S. Shimada: Setting the stage for flat-screen TV, MGHElectronics, Apr. 15 (1968) 92-101

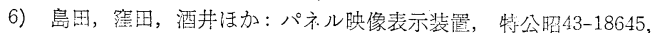
同44-22375, 同 47-15426 他, 实公昭46-12350, 同 47-14747 他

7）久保，竹田：カラー・ワイド・ディスプレイの開発，テレビ学会 方式国路研資，30-5 (1971)

8) 島田, 窪田: 分離着色式カラー䦼像再生方式の研究, テレビ学会 方式回路研資，3-3 (1967)

9）島田, 小笠原, 井上ほか：カラービデオ投写方式の㭘討之開発, 信学会画像工学研資，1972-12；TV画像処理シス研資， 8-2 (1972)

10) C.P. Gilmore: A 4'-by-6, Color TV Picture on your livingroom wall, Popular Science, Sep., (1972) 78-81 